\title{
Strategi Penanganan Event Pada Hotel The Laguna, A Luxury Collection Resort \& Spa, Nusa Dua, Bali
}

\author{
Gusti Ayu Sukasari, Putu Gede Parma, A.A.N.Y.M. Mahardika \\ Undiksha
}

\begin{abstract}
Abstrak
Penanganan event sangat penting dijaga kualitasnya karena hotel sebagai organizer adalah bagian dari kesuksesan acara yang diselenggarakan. Penelitian ini bertujuan untuk mengetahui bagaimana kualitas penanganan pada hotel The Laguna, a Luxury Collection Resort \& Spa, Nusa Dua, Bali. Sumber data yang diperoleh dengan mengadakan observasi dan wawancara langsung kepada narasumber yang menangani event secara langsung. Hasil penelitian dimasukkan secara deskriptif dan diperoleh hasil yang menunjukkan bahwa dalam penanganan event sudah berdasarkan Prosedur Operasional Standar (POS) hotel yang telah ditetapkan. Masalah yang sering timbul yaitu terdiri dari masalah terprediksi dan tidak bisa diprediksi. Masalah terprediksi dapat diantisipasi dengan mempelajari event yang akan berlangsung dari susunan acara yang sudah tersusun. Masalah yang tidak bisa diprediksi membutuhkan kebijaksanaan di lapangan sesuai masalah yang timbul. Oleh karena itu, komunikasi, koordinasi dan persiapan yang matang sangat diperlukan untuk bisa memberikan penanganan yang lebih maksimal sehingga acara yang terselenggara berjalan lancar dan sukses.
\end{abstract}

Kata kunci: event, kualitas, manajemen event, dan penanganan

Abstract

In Hotel, the quality of event organizing is important to be maintained. This study aimed at exploring the quality to find out how the quality of handling event at the Laguna, a Luxury Collection Resort \& Spa, Nusa Dua, Bali. The data were obtained through observation and face-to-face interview. The data were analyzed descriptively. The findings showed that the event organizing was based on Standard Operational Procedure (SOP). Some problems occured, some were predictable while others were unpredictable. The predicted problems were anticipated by studying the upcoming event carefully. The unpredicted problems required the operational officers's wisdom and solutions. Communication, coordination, and well-preparation were needed to have the smooth and successful event organizing.

Keywords: events, quality, management events, and handling

\section{Pendahuluan}

Pulau Bali merupakan salah satu provinsi yang memiliki fasilitas dan berpotensi menjadi tujuan wisata MICE. Berdasarkan dari fasilitas yang dimiliki, Bali kini tidak hanya menjadi daerah tujuan wisata, tetapi juga menjadi tempat diselenggarakannya berbagai event.

Berbagai instansi yang menyelenggarakan MICE di Bali sudah memiliki hotel pilihannya masing-masing, berdasarkan dari harga, lokasi, tujuan diselenggarakannya event tersebut serta yang tidak kalah penting adalah kualitas 
pelayanan dari hotel yang menjadi tempat terselenggaranya event tersebut. Salah satu hotel di Bali yang dipercaya menjadi tempat diselenggarakannya annual event dari suatu instansi setiap tahunnya adalah The Laguna, a Luxury Collection Resort \& Spa, Nusa Dua, Bali. Berlokasi di kawasan ITDC (Indonesia Tourism Development and Cooperation) Nusa Dua.

Kualitas pelayanan yang diberikan dalam sebuah event adalah salah satu faktor yang memengaruhi kepercayaan instansi untuk menyelenggarakan event di hotel yang sama setiap tahunnya. Sebagai hotel yang dipercaya tentunya harus dapat menjaga kualitas penanganan event yang diberikan.

Penanganan tidak hanya diberikan pada saat event itu berlangsung, penanganan mulai diberikan ketika hotel pertama kali menawarkan paket event seperti meeting, wedding, dinner, cocktail party kepada calon konsumen melalui surat elektronik, telepon, ataupun bertemu langsung. Penanganan diberikan oleh Sales MICE, Sales Event, Banquet, adalah pihak selanjutnya yang berperan untuk memberikan penanganan selama mempersiapkan event hingga event berakhir. Hasil perjanjian yang sudah dilakukan antara sales MICE dengan konsumen sangatlah penting sebagai acuan dalam penanganan selanjutnya. Penanganannya mulai dari persiapan seperti menyiapkan Banquet Event Order (BEO), pada saat event berlangsung, dan setelah event berlangsung seperti billing.

The Laguna, a Luxury Collection Resort \& Spa, Nusa Dua, Bali memiliki fasilitas yang memadai untuk penyelenggaraan event baik skala kecil maupun besar. Hal ini dikarenakan hotel The Laguna memiliki 287 kamar tidur lengkap dengan fasilitas dan memiliki 9 ruang pertemuan dan 4 tempat acara yang terletak di luar ruangan. Selain memiliki tempat acara yang memadai, pengadaan event di hotel The Laguna juga dilengkapi dengan berbagai fasilitas yang mendukung jalannya event.

Hotel The Laguna memiliki departemen yang khusus menangani event. Dalam operasionalnya, saat observasi awal, terlihat pola penyelenggaraan event serta kendala-kendala dalam pelaksanaannya. Peneliti tertarik untuk menggali lebih dalam mengenai aktivitas penyelenggaraan event di hotel The Laguna untuk mengetahui pola penyelenggaraannya serta kendala-kendala yang dihadapi.

Berdasarkan latar belakang tersebut, dapat diambil rumusan masalah sebagai berikut: (1) Apa saja kendala dalam penanganan event pada Hotel The 
Laguna, a Luxury Collection Resort \& Spa, Nusa Dua Bali. (2) Bagaimana strategi dalam penanganan event pada Hotel The Laguna, a Luxury Collection Resort \& Spa, Nusa Dua Bali

\section{Kajian Pustaka}

\subsection{Definisi Event}

Pengertian event menurut Sulistyowati dan Harisma (2016:4), adalah "event adalah sebuah program yang akan dilakukan secara terencana untuk suatu tujuan. Ragam acara amat banyak bergantung dari ide yang melandasi terlaksananya hal itu. Berbeda dengan kegiatan yang spontan, acara dilakukan berdasarkan rencana yang telah disusun sebelumnya". Sedangkan menurut Any Noor (2013:8), event merupakan kegiatan yang diselenggarakan untuk memperingati hal-hal penting sepanjang hidup manusia, baik secara individu atau kelompok yang terkait secara adat, budaya, tradisi, dan agama yang diselenggarakan untuk tujuan tertentu serta melibatkan lingkungan masyarakat yang diselenggarakan pada waktu tertentu.

Berdasarkan dari pengertian event di atas, maka dapat disimpulkan bahwa event merupakan kegiatan yang diselenggarakan untuk mencapai tujuan tertentu berdasarkan rencana yang telah disusun sebelumnya baik secara individu maupun kelompok. Menurut Any Noor (2013) event memiliki lima karakteristik, diantaranya keunikan, mudah rusak, tidak berwujud, suasana dan pelayanan, interaksi social. Selain karakteristik dalam suatu event, Any Noor (2013) membagi event berdasarkan kategori special event, diantaranya Leisure Event, Cultural Event, Personal Event, Organizational Event.

\subsection{Manajemen Event}

Menurut Hasibuan (2003:2), "Manajemen adalah ilmu dan seni mengatur proses pemanfaatan sumber daya manusia dan sumber-sumber lainnya secara efektif dan efisien untuk mencapai suatu tujuan tertentu". Sedangkan menurut Handoko (2003:8), "Manajemen adalah proses perencanaan, pengorganisasian, pengarahan dan pengawasan dengan memberdayakan anggota organisasi lainnya agar mencapai tujuan organisasi yang telah ditetapkan". Lebih lanjut, Suhendra (2015:142) mendefinisikan "Event Management dapat didefinisikan sebagai mengorganisir sebuah event yang dikelola secara profesional, sistematis, efisien, dan efektif yang kegiatannya meliputi dari konsep (perencanaan) sampai dengan pelaksanaan hingga pengawasan". 
Jadi, dapat disimpulkan bahwa manajemen event adalah proses mengorganisir sebuah event dengan memberdayakan anggota organisasi untuk mencapai tujuan yang telah ditetapkan yang kegiatannya meliputi perencanaan hingga evaluasi.

Menurut Hafidz (2007), dalam pembuatan suatu event terdapat beberapa tahapan, seperti proses pra-produksi/perencanaan, tahap produksi, dan tahap pasca produksi. Menurut Dewi dan Runyke (2013:85) manajemen event terdiri dari perencanaan, pengorganisasian, pengarahan dan pengimplementasian, serta pengendalian dan pengawasan.

2.3. Penelitian Terdahulu Tentang Meningkatkan Kualitas Penanganan Event

Penelitian tentang Strategi Penanganan Event telah banyak dilakukan oleh peneliti sebelumnya dapat dilihat pada tabel berikut:

\section{Tabel I Penelitian Terdahulu}

\begin{tabular}{|c|c|c|c|}
\hline No. & $\begin{array}{l}\text { Nama } \\
\text { Peneliti }\end{array}$ & Judul Penelitian & Hasil Penelitian \\
\hline 1. & $\begin{array}{l}\text { Narti dkk } \\
(2019)\end{array}$ & $\begin{array}{lrr}\text { Analisis } & \text { Kepuasan } \\
\text { Pelanggan SPG } & \text { Pro } \\
\text { Melalui CEI } & \text { Pada } \\
\text { Penanganan } & \text { Group } \\
\text { Event Sheraton Bali Kuta } \\
\text { Resort }\end{array}$ & $\begin{array}{l}\text { Pelanggan SPG Pro merasa puas } \\
\text { dengan penanganan event pada } \\
\text { Sheraton Bali Kuta Resort melalui CEI } \\
\text { dan dengan teknik analisis CSI dengan } \\
\text { presentase kepuasan yaitu } 77.43 \% \\
\text { yang diambil dari } 50 \text { responden pada } \\
\text { tahun } 2016 \text {. }\end{array}$ \\
\hline 2. & $\begin{array}{l}\text { Prihanto, } \\
\text { Agus } \\
\text { (2013) }\end{array}$ & $\begin{array}{lr}\begin{array}{lr}\text { Kepuasan } \\
\text { Konsumen }\end{array} & \begin{array}{r}\text { Loyalitas } \\
\text { Untuk Acarporat } \\
\text { Untura }\end{array} \\
\text { Terhadap MICE } & \text { Kualitas } \\
\text { Pelayanan Hotel HSTH }\end{array}$ & $\begin{array}{l}\text { Penelitian ini membuktikan hubungan } \\
\text { yang positif antara kepuasan dan } \\
\text { loyalitas, sehingga peningkatan } \\
\text { kepuasan dapat mendorong konsumen } \\
\text { untuk mengadakan acara kembali dan } \\
\text { merekomendasikan kepada konsumen } \\
\text { lain. Sesuai hasil analisis SEM bahwa } \\
\text { dimensi assurance adalah faktor } \\
\text { terbesar tingkat kepentingan pada } \\
\text { penilaian konsumen untuk usaha jasa. }\end{array}$ \\
\hline 3. & $\begin{array}{l}\text { Aida dkk } \\
(2014)\end{array}$ & $\begin{array}{lr}\text { Analisis } & \text { Kualitas } \\
\text { Pelayanan } & \text { Terhadap } \\
\text { Kepuasan } & \text { Konsumen } \\
\text { Pada Indika } & \text { Kreasindo } \\
\text { Event } & \text { Organizer } \\
\text { Pekanbaru } & \end{array}$ & $\begin{array}{l}\text { Penelitian ini menggunakan metode } \\
\text { regresi lincar berganda (multiple } \\
\text { regression) dengan pengolahan data } \\
\text { menggunakan Program SPSS For } \\
\text { Windows versi } 18.00 \text {. terdapat } \\
\text { pengaruh yang signifikan antara } \\
\text { kualitas pelayanan yang dilihat variabel } \\
\text { bukti fisik, perhatian, kehandalan, daya } \\
\text { tanggap dan jaminan pelayanan }\end{array}$ \\
\hline
\end{tabular}




\begin{tabular}{|c|c|c|c|}
\hline & & & $\begin{array}{l}\text { terhadap kepuasan konsumen pada } \\
\text { Indika Kreasindo Event Organizer } \\
\text { Pekanbaru. }\end{array}$ \\
\hline 4. & $\begin{array}{l}\text { Andriani } \\
\text { (2018) }\end{array}$ & $\begin{array}{ll}\text { Proses } & \text { Pelaksanaan } \\
\text { Event Meeting Di } & \text { Di } \\
\text { Banquet } & \text { Section Hotel } \\
\text { Premiere Pekanbaru }\end{array}$ & 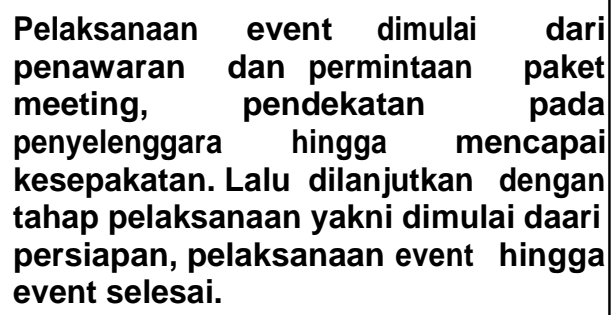 \\
\hline 5. & $\begin{array}{l}\text { Widyatatik } \\
\text { dkk (2011) }\end{array}$ & 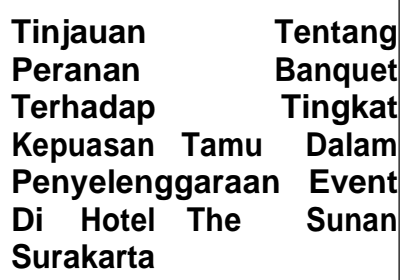 & $\begin{array}{l}\text { Faktor pendidikan, faktor kemampuan } \\
\text { kerja, dan faktor tanggung jawab pada } \\
\text { karyawan sangat berpengaruh } \\
\text { terhadap tingkat kepuasan tamu. }\end{array}$ \\
\hline 6. & $\begin{array}{l}\text { Salma dkk } \\
(2018)\end{array}$ & $\begin{array}{lr}\text { Pengaruh } & \text { Kerjasama } \\
\text { Kitchen Section } & \text { Dengan } \\
\text { Banquet } & \text { Section } \\
\text { Terhadap } & \text { Kualitas } \\
\text { Penyelenggaraan Event } \\
\text { di Hotel Best } & \text { Western } \\
\text { Premier Solo Baru }\end{array}$ & $\begin{array}{l}\text { Peningkatan kualitas penyelenggaraan } \\
\text { event antara kerjasama Kitchen Section } \\
\text { dengan Banquet Section bekerja } \\
\text { sangat berpengaruh. Pekerjaan yang } \\
\text { dikerjakan harus sesuai dengan } \\
\text { standar yang diberlakukan di hotel. }\end{array}$ \\
\hline
\end{tabular}

Penelitian ini berbeda dari penelitian-penelitian sebelumnya karena pada penelitian ini, penulis menekankan pada strategi penanganan event di Hotel The Laguna, Nusa Dua, Bali. Pada penelitian ini, strategi penanganan event ini dilakukan oleh sales event pada Hotel The Laguna. Sedangkan pada penelitian sebelumnya, peningkatan kualitas event dengan peningkatan kerjasama antara kitchen section dan banquet section.

\section{Metodologi Penelititan}

\subsection{Metodologi Penelitian}

Penelitian ini menggunakan rancangan Deskriptif Kualitatif dengan memaparkan data yang didapat melalui proses wawancara dan observasi yang 
dilakukan di lokasi penelitian bersama dengan para responden yang terkait dengan penelitian ini.

\subsection{Lokasi Penelitian}

Penelitian ini dilakukan di Hotel The Laguna, a Luxury Collection Resort \& Spa, Nusa Dua, Bali. Berlokasi di kawasan Pariwisata Nusa Dua Lot N2 Nusa Dua, Bali 80363.

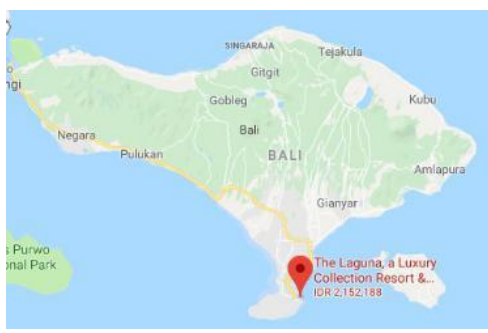

Gambar I. Peta Hotel The Laguna, Nusa Dua Bali

Sumber : www.google.com. 2019

\subsection{Jenis Data}

Jenis data yang akan diambil dalam penelitian ini adalah data primer dan data sekunder. Data primer adalah data yang diambil langsung dari lokasi penelitian, bersumber dari data yang diberikan oleh subjek-subjek penelitian melalui proses observasi dan wawancara. Data Sekunder adalah data yang didapat dari buku-buku pariwisata dan perhotelan, jurnal akademis, artikel penelitian, skripsi, dan situs web yang terkait dengan strategi penanganan event. 3.4. Subjek dan Objek Penelitian

Subjek penelitian yang dimaksud adalah Event Organizer atau yang bertugas sebagai pihak EO pada hotel ini adalah Event Manager, dan Event Admin, kemudian subjek lainnya adalah Assistant Banquet Manager, Banquet Supervisor, Commis Chef 2 pada Kitchen Banquet, IT Technician, dan Engineering. Para subjek ini dipilih karena lingkup pekerjaannya adalah terjun langsung menangani event, sehingga diharapkan dapat memberikan data yang lebih akurat mengenai penelitian yang dilakukan. Adapun objek dari penelitian ini adalah kualitas penanganan event pada Hotel The Laguna, a Luxury Collection Resort \& Spa, Nusa Dua, Bali.

\subsection{Teknik Pengumpulan Data}

Teknik wawancara ini dilakukan dengan tanya jawab langsung kepada para responden diantaranya Event Manager, Event Admin, Assistant Banquet Manager, Banquet Supervisor, Commis Chef 2 pada Kitchen Banquet, IT 
Technician, dan Engineering agar mendapatkan informasi yang tepat. Pertanyaan telah disusun terlebih dahulu berdasarkan pedoman wawancara, lalu pertanyaan diajukan pada saat wawancara berlangsung.

Teknik dokumentasi dilakukan untuk mengumpulkan data dan dokumen yang berkaitan dengan penelitian serta mengumpulkan gambar-gambar yang berkaitan dengan penelitian sebagai acuan dalam penyelesaian penelitian ini.

\subsection{Metode Analisis Data}

Metode analisis data yang digunakan untuk keseluruhan data adalah Deskriptif Kualitatif yaitu menguraikan dan memaparkan data yang telah diperoleh dari lokasi penelitian melalui proses observasi dan wawancara yang berhubungan dengan strategi penanganan event. Data kemudian dikumpulkan, dicatat serta disortir, selanjutnya dianalisis sehingga data dapat dipahami oleh pembaca, lalu dari data tersebut dapat ditarik kesimpulan dan kemudian disajikan dalam pembahasan dan kesimpulan pada tulisan ini. Tujuan metode ini adalah untuk menggambarkan secara sistematis terhadap fenomena yang diteliti.

\section{Hasil Penelitian dan}

\section{Pembahasan 4.1. Gambaran Umum}

Sejarah awal The Laguna a Luxury Collection Resort \& Spa berawal dari nama Sheraton Lagoon Resort Bali yang berada di bawah ITT Sheraton Corporation yang diresmikan pada 16 Desember 1991. Kemudian, dengan adanya kebijakan aturan pemerintah untuk menggunakan nama dengan Bahasa Indonesia, sehingga pada tahun 1993 Sheraton Lagoon berubah menjadi Sheraton Laguna. Pada Oktober 1997 Starwood Hotels \& Resort Worldwide, Inc., mengambil alih ITT Sheraton Corporation. Pada 1 September 2006 Sheraton Laguna Nusa Dua, Bali secara resmi berganti nama menjadi The Laguna Resort \& Spa Nusa Dua, Bali dan murni menjadi The Luxury Collection dari Starwood Hotels \& Resort Worldwide, Inc. Pada 23 September 2016, Starwood Hotels \& Resort secara resmi bergabung dengan Marriott. The Laguna, a Luxury Collection Resort \& Spa, Nusa Dua Bali berlokasi di kawasan Pariwisata Nusa Dua Lot N2 Nusa Dua, Bali. Memiliki 287 kamar tidur lengkap dengan fasilitas yang mencerminkan nuansa luxury, Resort ini juga memiliki 7

kolam renang dengan luas $5.000 \mathrm{~m}^{2}$, terdiri dari kolam renang anak-anak dan kolam renang berpasir dan memiliki air terjun yang menenangkan serta kebun tropis yang indah. Selain itu, terdapat beberapa outlet yang melayani pemesanan 
makanan dan minuman, spa dan fitness center, tempat rekreasi, ruang pertemuan dan berbagai fasilitas lainnya, serta dilengkapi dengan beberapa program hotel bagi tamu yang ingin menghabiskan waktu di dalam hotel.

\subsection{Pola Penyelenggaraan Event}

Proses penanganan suatu event tidak instan, diperlukan waktu yang panjang dan persiapan yang matang serta eksekusi yang tepat. Berdasarkan hasil observasi yang peneliti lakukan, berikut adalah pola penyelenggaraan event. Pertama, sales event akan menjual paket yang diminati tamu. Sales event akan mengumpulkan informasi dari klien berdasarkan keinginan tamu yang akan hadir. Informasi tersebut akan digunakan sebagai acuan dalam pembuatan kontrak perjanjian, Banquet Event Order (BEO) dan Guest Information Sheet (GIS). Apabila sudah mencapai kata sepakat, maka sales event akan mempersiapkan kontrak perjanjian. Kontrak perjanjian akan ditandatangani oleh kedua belah pihak yakni klien dan sales event.

Berdasarkan informasi yang sudah didapatkan, maka sales event akan menyiapkan Guest Information Sheet (GIS), yang berisikan data-data tamu seperti tanggal kedatangan, tanggal keberangkatan, jadwal event, special request yang diperlukan, harga paket sesuai perjanjian dan informasi penting lainnya. GIS akan dikirim ke seluruh Department Head, departemen yang terkait serta termasuk General Manager agar segala informasi dapat diketahui oleh seluruh karyawan sebelum grup tersebut datang. Sales event juga akan menyiapkan Banquet Event Order (BEO). BEO berisikan informasi kebutuhan tamu dan akan menjadi acuan dalam menangani event. Informasi yang tercantum pada BEO diantaranya nama event, nama grup, person in-charge, tanggal berlangsungnya event, menu makanan yang akan dihidangkan, jenis minuman yang akan dihidangkan, setup yang akan digunakan, jumlah mikrofon yang diperlukan, lokasi event tersebut berlangsung, informasi pembayaran dan masih banyak lagi lainnya. BEO juga berisikan susunan acara dari grup tersebut, sehingga seluruh karyawan yang bertugas akan mengetahui acara dari grup tersebut. BEO akan dikirim ke departemen yang terkait, sehingga masing-masing departemen tersebut dapat mempersiapkan hal-hal yang diperlukan dan menentukan penanganan seperti apa yang harus diberikan. Selanjutnya, sales event akan mengadakan rapat bersama departemen yang terlibat dalam menangani event tersebut yang akan membahas mengenai informasi yang 
tercantum pada GIS dan BEO, serta informasi-informasi penting lainnya yang diperlukan. Pertemuan tersebut melibatkan Food \& Beverage Service Department seperti perwakilan dari Banquet Section dan F\&B Manager, kemudian Food Production seperti Executive Chef dan CDP banquet kitchen, serta ngineering yaitu assistant chief engineering. Pertemuan ini bertujuan untuk menyatukan pendapat sehingga persiapan event dapat dilakukan dengan maksimal.

Setelah melaksanakan pertemuan, masing-masing departemen terkait akan melakukan persiapan berdasarkan acuan dari BEO. Tiba saatnya event berlangsung, masing-masing departemen akan melakukan pengecekan kembali sebelum event dimulai, hal ini diperlukan agar mengetahui apakah semua sudah beroperasi dengan baik. Seorang event organizer akan tetap berada di hotel untuk mengawasi jalannya event. Jika event tersebut sudah selesai, langkah selanjutnya adalah sales event mengumpulkan bill dari restoran, banquet, kamar, laundry, spa dan bill lainnya yang ada untuk selanjutnya akan diselesaikan oleh klien dengan pembayaran baik cash ataupun dengan transfer. Jika event tersebut sudah selesai dan klien sudah check out, maka sistem secara otomatis akan mengirimkan kuisioner mengenai tanggapan dan kesan dari klien tersebut selama mendapatkan pelayanan di hotel. Tanggapan ini akan otomatis masuk dalam sistem hotel dan baik maupun buruknya tanggapan klien akan terlihat pada sistem. Sistem ini dapat diakses oleh seluruh karyawan hotel termasuk General Manager, sehingga dari data ini akan dijadikan evaluasi terhadap penanganan yang lebih baik kedepannya.

\subsection{Kendala dalam Penanganan Event}

Berdasarkan komentar dari para responden, kualitas penanganan event ditentukan oleh beberapa hal diantaranya, yang pertama adalah perencanaan yang tepat, perencanaan suatu event mencakup konsep event, perencanaan kebutuhan yang diperlukan, susunan acara, peserta yang hadir, teknis pelaksanaan, dan masih banyak lagi. Selanjutnya adalah persiapan yang matang, Persiapan adalah pekerjaan yang dilakukan setelah rencana-rencana tersusun. Selanjutnya adalah kelengkapan susunan acara, melalui susunan acara setiap departemen dapat memprediksi dan menyiapkan dengan baik keperluan selama event berlangsung, sehingga penanganan yang diberikan menjadi lebih baik dan tentu saja memengaruhi kualitas suatu event. Selanjutnya 
adalah komunikasi. Penanganan suatu event selanjutnya ditentukan oleh komunikasi. Komunikasi sangat dibutuhkan agar penanganan event dapat dilakukan menjadi lebih maksimal. Produk dan harga juga dapat memengaruhi penanganan suatu event. Produk yang dijual oleh sales department ataupun sales event adalah berupa paket-paket event dengan penawaran yang sudah diharapkan oleh pelanggan. Selanjutnya adalah fasilitas, fasilitas-fasilitas ini tentunya sangat membantu jalannya suatu event sehingga kualitas yang dihasilkan menjadi lebih baik. Selanjutnya adalah kualitas pelayanan. Melalui pelayanan yang diberikan, maka klien akan merasa diperhatikan dan terbantu, sehingga penanganan event menjadi lebih maksimal dan kualitasnya menjadi lebih baik. Selain itu jumlah karyawan dan pemahaman karyawan terhadap event juga dapat memengaruhi penanganan suatu event. Untuk bisa memberikan pelayanan yang terbaik kepada para tamu jumlah karyawan harus memenuhi kebutuhan. Pemahaman karyawan terhadap event yang berlangsung juga sangat memengaruhi kualitas penanganan suatu event. Jika karyawan mengetahui alur event serta kebutuhan selama event berlangsung, maka kualitas suatu event menjadi baik.

Keberhasilan ini akan ditentukan berdasarkan kualitas penanganan yang diberikan. Namun, kondisi di lapangan berbeda dengan faktor penentu tersebut. Berdasarkan hasil wawancara yang dilakukan dengan beberapa responden, maka dapat ditemukan permasalahan yang muncul, permasalahan-permasalahan tersebut, diantaranya permintaan tamu yang mendadak (Last minute request), terkadang pelaksanaan suatu event terjadi diluar perencanaan dan persiapan. Kejadian ini memiliki dua sifat, yaitu terprediksi dan tidak terprediksi. Selanjutnya adalah keterbatasan barang dan alat. Suatu event tidak bisa berjalan dengan lancar jika barang dan alat yang digunakan terbatas. Selanjutnya adalah permintaan tamu diluar menu dan Banquet Event Order (BEO). Pada BEO terdapat menu makanan yang akan dihidangkan, namun seringkali tamu meminta makanan yang diluar BEO. Selanjutnya adalah pembaruan sistem informasi hotel.

Pada akhir tahun 2018, sistem komputer yang digunakan pada event department diganti dan proses memasukkan data harus lengkap dan cukup lama. Selanjutnya adalah jumlah karyawan dan pemahaman karyawan terhadap event yang kurang. Ketika ada event yang berlangsung dengan peserta ratusan orang, maka karyawan yang bekerja bukan hanya dari tim banquet tetapi juga 
karyawan dari otlet lain, sehingga karyawan yang bertugas berganti-ganti. Karena karyawan yang bertugas berganti-ganti, maka informasi terhadap event yang berlangsung menjadi tidak jelas. Selanjutnya adalah kesalahan dalam berkomunikasi. Jika komunikasi tidak diperhatikan, ini akan sangat berpengaruh terhadap pelaksanaan event. Selanjutnya adalah keterbatasan waktu. Perencanaan dan persiapan suatu event membutuhkan waktu yang cukup lama. Jika memiliki waktu yang terbatas, maka persiapan yang dilakukan tidak akan maksimal

\subsection{Solusi dalam Meningkatkan Kualitas Penanganan Event}

Berdasarkan permasalahan yang muncul, para responden juga mengutarakan mengenai upaya yang bisa dilakukan untuk dapat menghindari permasalahan tersebut serta solusi yang diperlukan diantaranya, persiapan yang matang dan pembuatan rencana lain. Persiapan yang matang merupakan salah satu solusi untuk bisa menghindari permasalahan yang muncul. Persiapan juga dilakukan untuk membuat rencana lain seperti persiapan plan $B$, plan $C$ ataupun plan D. Ini merupakan komponen yang penting yang dapat digunakan sebagai solusi untuk menghindari pernasalahan yang timbul. Selanjutnya adalah komunikasi dan koordinasi lebih ditingkatkan. Komunikasi dan koordinasi harus dapat dibangun antara tim yang bertugas dalam menangani event, dan pihak hotel dengan tamu. Dengan komunikasi dan koordinasi yang baik kepada tamu, pihak hotel dapat mempersiapkan dan memberikan penanganan yang terbaik kepada tamu, sehingga keinginan tamu dapat terpenuhi dengan baik. Selanjutnya adalah persediaan barang dan alat memadai. Permasalahan yang berkaitan dengan persediaan barang maupun alat seharusnya dapat dihindari dengan memprediksi event yang akan berlangsung dikemudian hari. Solusi selanjutnya adalah memberi pelayanan yang lebih baik. Suatu event dapat berjalan lancar jika seluruh susunan acara berjalan dengan baik dan tanpa halangan serta suatu grup akan kembali lagi menggunakan hotel tersebut jika pelayanannya bagus. Selanjutnya adalah memberi masukan agar permintaan last minute dapat terpenuhi. Jika ada last minute request dari para tamu, tim banquet ataupun event organizer akan berusaha untuk memenuhi kebutuhannya, menindaklanjuti permasalahan ini, event organizer akan berusaha untuk membangun komunikasi yang baik kepada para tamu. Selanjutnya adalah menggunakan barang yang ada dengan tetap mengutamakan kualitas, dengan 
keterbatasan alat, pihak hotel akan selalu berupaya untuk memenuhi kebutuhan event, pihak hotel akan berusaha menggunakan barang dan alat yang ada dengan kualitas yang sama, namun jika kondisi buruk terjadi, pihak hotel akan menyewa di tempat penyewaan barang dan alat. Selanjutnya adalah mempersiapkan keperluan event. Pihak hotel harus menyiapkan barang atau peralatan yang tidak dicantumkan pada BEO, hal ini dilakukan agar dapat menjaga kelancaran event. Selanjutnya adalah memberikan saran kepada tamu sebagai alternatif lain jika barang sedang tidak ada dan Mengikuti training sistem baru.

Selain upaya yang perlu dilakukan untuk menghindari permasalahan yang muncul, kita juga dapat memaksimalkan kualitas suatu event dengan melakukan peningkatan terhadap hal-hal yang dapat memengaruhi penanganan event. Berdasarkan hasil wawancara, hal-hal yang perlu ditingkatkan untuk membuat kualitas event menjadi lebih baik, diantaranya, Perencanaan yang matang. Jika kualitas suatu event ingin ditingkatkan, tentunya perencanaan juga harus dimaksimalkan, hal ini bertujuan untuk menghindari permasalahan yang mungkin muncul dan mengurangi kemungkinan mendapatkan komplin. Selanjutnya adalah Kinerja para SDM. Untuk bisa mendapatkan kualitas event yang baik, maka peningkatan kinerja para SDM perlu dilakukan. Selanjutnya adalah komunikasi, jika ada satu hal saja yang tidak terkomunikasikan dengan baik, maka akan sangat memengaruhi keberlangsungan event tersebut. Kemudian adalah tindak lanjut, jika ada pekerjaan yang memerlukan tindakan lebih lanjut, hendaknya harus terakomodir dengan baik, sehingga suatu pekerjaan dapat tertuntaskan. Selanjutnya adalah menyiapkan rencana lain. Suatu event tidak bisa hanya mengandalkan satu perencanaan saja. Suatu event agar dapat terlaksana dengan baik, maka seorang event organizer harus bisa menyiapkan rencana jika hal buruk terjadi.

\section{Pembahasan}

Berdasarkan hasil penelitian yang dilakukan dengan metode observasi serta wawancara kepada 10 responden, dapat ditemukan bahwa unsur-unsur manajemen event sangat memengaruhi penanganan suatu event yang akan berimplikasi pada kualitas suatu event. Hotel seharusnya melakukan perencanaan dan persiapan yang lebih matang sehingga pada saat pelaksanaan, penanganan yang diberikan terorganisir dan maksimal. Namun, 
kenyataan yang terjadi di lapangan, terdapat unsur-unsur manajemen yang tidak terlaksana dengan baik.

Usaha penyelenggaraan event yang baik di hotel The Laguna dalam beberapa kesempatan mengalami kendala. Kendala-kendala yang muncul bisa jadi sudah diantisipasi atau tidak terantisipasi. Kendala-kendala yang dihadapi diselesaikan menggunakan acuan Standard Operational Procedure (SOP) yang berlaku berdasarkan ketentuan dan kebijakan dari perusahaan dan hotel, selain itu, terdapat juga penanggulangan kendala yang tidak berdasarkan SOP, namun menggunakan kebijaksanaan di lapangan. Oleh karena itu, sesuai perbandingan dari teori Suhendra (2015:142) tentang pengertian event management yaitu, Event Management dapat didefinisikan sebagai mengorganisir sebuah event yang dikelola secara profesional, sistematis, efisien, dan efektif yang kegiatannya meliputi dari konsep perencanaan sampai dengan pelaksanaan hingga pengawasan. Kemudian berdasarkan teori dari Dewi dan Runyke (2013:85) manajemen event terdiri dari perencanaan, pengorganisasian, pengarahan dan pengimplementasian, serta pengendalian dan pengawasan. Strategi yang dapat digunakan adalah menerapkan unsur-unsur event management. Event management terdiri dari perencanaan, pengorganisasian, pengarahan, dan pengimplementasian serta pengendalian dan pengawasan. Selanjutnya adalah mengevaluasi kesalahan sebelumnya. Jika terjadi kesalahan ataupun permasalahan dapat dicarikan solusi untuk perbaikan event selanjutnya. Permasalahan ini dapat ditanggulangi dengan memikirkan keputusan-keputusan yang diambil sebagai jalan keluar. Strategi selanjutnya adalah mengkomunikasikan dengan baik kepada seluruh departemen terkait. Segala bentuk permasalahan dan permintaan tamu seharusnya dikomunikasikan dengan baik, sehingga informasi dapat diterima oleh semua orang dan koordinasi tim bisa lebih maksimal. Terakhir adalah melakukan briefing kepada seluruh staf yang bertugas. Event organizer sebagai informan dapat memberikan arahan dan membahas susunan acara kepada seluruh anggota tim yang bertugas, sehingga segala bentuk informasi yang terprediksi dapat ditangani, hal ini juga dapat dilakukan agar meminimalisir kesalahan komunikasi yang terjadi selama memberikan penanganan event.

\section{Simpulan}

Berdasarkan hasil penelitian yang telah dilakukan, maka dapat diambil 
simpulan, diantaranya (1) Terdapat beberapa permasalahan yang timbul pada saat penanganan event, permasalahan-permasalahan tersebut tidak hanya dialami oleh event organizer saja, tetapi juga seluruh departemen terkait yang ikut terjun langsung menangani event. Permasalahan-permasalahan tersebut diantaranya: permintaan tamu yang mendadak (last minute request), keterbatasan alat dan barang, permintaan tamu diluar menu atau BEO, pembaruan sistem informasi hotel, jumlah karyawan dan pemahaman karyawan terhadap event, kesalahan dalam berkomunikasi, serta keterbatasan waktu. (2) Solusi yang dapat digunakan dari permasalahan yang ditemukan adalah mempersiapkan segala sesuatunya dengan baik, mengkomunikasikan dengan lebih baik, ketersediaan barang dan alat memadai, pelayanan yang baik, memberi masukan dan saran kepada tamu untuk keperluan yang mendadak, mempergunakan barang dan alat yang ada dengan tetap mempertahankan kualitas, mengikuti training sistem baru, memberikan briefing kepada staf yang bertugas sebelum event dimulai. Strategi yang dapat digunakan untuk mengatasi permasalahan tersebut adalah menerapkan unsur-unsur manajemen, mengevaluasi permasalahan sebelumnya, mengkomunikasikan dan saling berkoordinasi antar departemen, serta melakukan pengarahan sebelum event dimulai.

\section{Daftar Pustaka}

Aida dkk. 2014. Analisis Kualitas Pelayanan Terhadap Kepuasan Konsumen Pada Indika Kreasindo Event Organizser Pekanbaru. Universitas Riau. Tersedia pada https://jom.unri.ac.id/index.php/JOMFEKON/article/view/5418. Diakses pada 10 April 2019, pukul 12.40.

Andriani. 2018. Proses Pelaksanaan Event Meeting Di Banquet Section Hotel Premiere Pekanbaru. Jom Fisip. Vol. 5. No. 1. Tersedia pada https://media.neliti.com/media/publications/199482-proses-pelaksanaanevent-meeting-di-banq.pdf. Diakses pada 10 April 2019, pukul 12.45.

Dewi, Mutia dan Runyke, Marcha. 2013. Peran Public Relations Dalam Manajemen Event: Studi Terhadap Peran Public Relations Galleria Mall dan Plaza Ambarrukmo Dalam Pengelolaan Event Tahun 2013. Jurnal Komunikasi. Vol. 8. No. 1. Hal. 85. Tersedia pada https://journal.uii.ac.id/jurnal-komunikasi/article/view/6468/5827. Diakses pada 10 April 2019, pukul 14.24.

H. Malayu S.P. Hasibuan. 2003. Manajemen, Cetakan Kedua. Jakarta: Bumi Aksara. 
Hafidz, Ibnu Novel. 2007. Mengulik Bisnis Event Organizer. Yogyakarta: Gava Media

Handoko, Hani T. 2003. Manajemen. Yogyakarta: BPFE

Lupiyoadi dan Hamdani. 2001. Manajemen Pemasaran Jasa: Teori dan Praktek, Edisi Pertama. Jakarta: Salemba Empat.

Narti dkk. 2019. "Analisis Kepuasan Pelanggan SPG Pro Melalui CEI Pada Penanganan Group Event Sheraton Bali Kuta Resort”. Forum Manajemen Vol 17, No. 1. Tersedia pada https://drive.google.com/file/d/1hSosQJH11DxPKd4MTEo8sluKay1Ti9vO/view. Diakses pada 10 April 2019, pukul 12.05.

Noor, Any. 2013. Manajemen Event Edisi Revisi. Bandung: Alfabeta

Prihanto, Agus dkk. 2013. Kepuasan dan Loyalitas Konsumen Korporat Untuk Acara MICE Terhadap Kualitas Pelayanan Hotel HSTH. Sekolah Tinggi Pariwisata Sahid Surakarta. Tersedia pada http://puslit2.petra.ac.id/ejournal/index.php/man/article/view/18776. Diakses pada 10 April 2019, pukul 13.32.

Salma dkk. 2018. Pengaruh Kerjasama Kitchen Section Dengan Banquet Section Terhadap Kualitas Penyelenggaraan Event Di Hotel Best Western. Sekolah Tinggi Pariwisata Sahid Surakarta. Tersedia pada http://jurnal.stpss.ac.id/index.php/JPI/article/view/124/107. Diakses pada 10 April 2019, pukul 12.35.

Suhendra, Fernando. 2015. Manajemen Event Pameran Pernikahan Tradisional Lintaswarna. Universitas Islam Bandung.

Sulistiono, Ari Budi. 2010. Pengaruh Kualitas Pelayanan, Fasilitas, dan Lokasi Terhadap Keputusan Menginap. Universitas Diponegoro Semarang. Tersedia pada http://eprints.undip.ac.id/22627/1/full_skripsi.pdf. Diakses pada tanggal 17 Mei 2019, pukul 23.13.

Sulistyowati, Harisma. 2015. Manajemen Event JPD2316. Diktat. Politeknik Negeri Jakarta.

Widyatatik dkk. Tinjauan Tentang Peranan Banquet Service Terhadap Tingkat Kepuasan Tamu Dalam Penyelenggaraan Event Di Hotel The Sunan Surakarta. Sekolah Tinggi Pariwisata Surakarta. Tersedia pada http://jurnal.stpss.ac.id/index.php/JPI/article/view/38/29. Diakses pada 10 April 2019, pukul 13.05.

www.google.com. 20019. Peta Hotel The Laguna, Nusa Dua Bali. Tersedia pada https://www.google.com/maps/place/The+Laguna+Resort+\%26+Spa+Nusa +Dua,+Bali+The+Luxury+Collection/@8.4322133,115.1089801,10z/data =!4m5!3m4!1s0x0:0xdb311c654377bf82! $8 \mathrm{~m} 2 ! 3 \mathrm{~d}-8.7973822 ! 4 \mathrm{~d} 115.2307704$. Diakses pada tanggal 25 April 2019, pukul 10.00 . 